Article

\title{
Estimation of Cargo Handling Capacity of Coastal Ports in China Based on Panel Model and DMSP-OLS Nighttime Light Data
}

\author{
Aoshuang Liu ${ }^{1}$, Ye Wei ${ }^{1, *}$, Bailang Yu ${ }^{2}$ and Wei Song ${ }^{3}$ \\ 1 School of Geographical Sciences, Northeast Normal University, Changchun 130024, China; \\ liuas935@nenu.edu.cn \\ 2 Key Laboratory of Geographic Information Science (Ministry of Education), East China Normal University, \\ Shanghai 200241, China; blyu@geo.ecnu.edu.cn \\ 3 Department of Geography and Geosciences, University of Louisville, Louisville, KY 40292, USA; \\ wei.song@louisville.edu \\ * Correspondence: weiy742@nenu.edu.cn; Tel.: +86-177-9000-6582
}

Received: 21 January 2019; Accepted: 6 March 2019; Published: 10 March 2019

\begin{abstract}
The cargo handling capacity of a port is the most basic and important indicator of port size. Based on the Defense Meteorological Satellite Program-Operational Linescan System (DMSP-OLS) nighttime light data and panel model, this study attempts to estimate the cargo handling capacity of 28 coastal ports in China using satellite remote sensing. The study confirmed that there is a very close correlation between DMSP-OLS nighttime light data and the cargo handling capacity of the ports. Based on this correlation, the panel data model was established for remote sensing-based estimation of cargo handling capacity at the port and port group scales. The test results confirm that the nighttime light data can be used to accurately estimate the cargo handling capacity of Chinese ports, especially for the Yangtze River Delta Port Group, Pearl River Delta Port Group, Southeast Coastal Port Group, and Southwest Coastal Port Group that possess huge cargo handling capacities. The high accuracy of the model reveals that the remote sensing analysis method can make up for the lack of statistical data to a certain extent, which helps to scientifically analyze the spatiotemporal dynamic changes of coastal ports, provides a strong basis for decision-making regarding port development, and more importantly provides a convenient estimation method for areas that have long lacked statistical data on cargo handling capacity.
\end{abstract}

Keywords: coastal ports; cargo handling capacity; nighttime lights; panel model; spatiotemporal dynamic analysis

\section{Introduction}

In recent years, the process of globalization has continued to deepen and the volume of international trade in goods has increased constantly. Due to the advantages of large transportation volume and low freight rate, maritime transportation accounts for more than $90 \%$ of international freight transportation. Coastal ports have become important nodes for trade between countries, and the cargo handling capacity (also known as Cargo throughout) is the most basic and important indicator for measuring the development status of coastal ports. As defined by China Ports \& Harbors Association, the cargo handling capacity is "the weight of loaded and unloaded goods that enter and exit the port area by waterway during the reporting period," usually in tons. The index has been widely used to evaluate the scale and comprehensive capacity of sea ports [1-3]. The calculation methods of cargo handling capacity include calculating the inbound throughput of the cargo that enters the port by waterway and is then unloaded, calculating the outbound throughput of the cargo that is loaded and shipped out of the port, and calculating the inbound and outbound throughputs 
of the transit cargo that enters the port by waterway and is shipped out of the port by waterway after unloading and loading processes. The cargo handling capacity is calculated after the completion of cargo loading and unloading and the handling of transfer formalities by the ship at the port. The weight of the cargoes, such as livestock, poultry, and light cargo, of which the actual weight cannot be obtained, is converted by the use of coefficients. Accurate estimation of the cargo handling capacity can provide a scientific basis for the future planning and construction of customized and elaborate and efficient coastal ports, which plays an important role in further understanding port development status, exploring the spatiotemporal dynamics of ports, discerning the new rules of port development, and improving port competitiveness.

Previously, statistical data was the predominant basis for research on cargo handling capacity. For example, when analyzing cargo distribution of Brazilian ports based on fuzzy logic and social networks, Sun and Tan collected the national statistical data on cargo handling capacity [4]; Eddie et al. used the cargo handling capacity data released by the Statistics Department of Hong Kong Special Administrative Region to analyze the response of Hong Kong Port's cargo handling capacity to factor cost differentials [5]. In studying the impacts of exchange rate changes, global economic activities, and Baltic dry index (BDI) fluctuations on the cargo handling capacity of South Korean ports, Chang also utilized cargo handling capacity data from national statistical data [6]. Dependence on statistical data not only requires a high amount of effort in collecting and sorting data, but also often suffers from the different statistical caliber of various sets of data, as well as the lack of statistical data in certain cases (e.g., war zones). Therefore, there is a need for stable and faster data sources for better port studies.

Field research indicates that in order to facilitate day- and nighttime operation, the ships berthing at coastal ports at night for loading and unloading cargo, as well as those in the cargo handling area, usually keep their lights on. The more ships there are that are loading and unloading cargoes, the larger the cargo volume and the higher the light intensity. Based on this feature of coastal ports, we envisaged the possibility of estimating the port throughput by observing the light intensity of ports at night. In terms of collecting nighttime light data, the Defense Meteorological Satellite Program-Operational Linescan System (DMSP-OLS) nighttime light data is a good data source that is widely used to establish models and estimate socio-economic factors [7-15]. Nighttime lights could be used as a proxy for some economic variables, especially in areas or times where other data are insufficient or unavailable [16,17]. The DMSP is made up of military meteorological remote-sensing satellites launched by the United States and carries the OLS sensor that usually operates at night. The OLS sensor is four times more sensitive than conventional sensors, especially to visible light and near-infrared light [18]. The OLS sensor is designed to collect low-light imaging data to detect moonlight reflected by the clouds. However, it was quickly discovered that light radiation associated with human activities can also be observed when clouds are not present [16,19-21]. For instance, data on light sources such as city lights, gas flares, firelight, and vessel lights can be collected by DMSP-OLS sensors [22-25]. As a result, many scholars have applied nighttime light data to the study of fishing boats, cargo volumes, ports, etc. For example, Elvidge et al. used nighttime lights to detect and trace ships giving off strong light signals [24,26,27]. Shi et al. used NPP-VIIRS data to estimate freight volume [28]. Li et al. used the DMSP-OLS nighttime light imagery to provide comprehensive scores for port economics of major cities in the Yangtze River Basin [29]. Although these studies are carried out around seaports and offshore areas, quantitative remote sensing studies on cargo handling capacity have not been reported. This paper attempted to fill this void by using DMSP-OLS nighttime light data to estimate the cargo handling capacity of seaports.

Panel data analysis is a regression analysis method based on spatio-temporal data, which is commonly used in trade and logistics research. For example, Chu used panel data to study logistics and economic growth [30]. Lakew et al. used panel data to analyze air cargo costs in the United States, airport traffic and airport delays in the aviation industry [31]. Guo et al. studied the relationship among carbon emissions, GDP, and logistics by using a panel data model and a combination of statistics and econometrics theory [32]. Considering data as a panel, not just a cross-sectional or time series data, 
has multiple advantages. Panel data have more information, more variability, more degrees of freedom, and other properties. The panel data can be adjusted dynamically, and the appropriate model can be generated [33-35]. In recent years, panel data have also been gradually applied in the remote sensing field. For instance, Shi et al. performed the panel data analysis of spatiotemporal emission dynamics of Chinese $\mathrm{CO}_{2}$ based on DMSP-OLS stable night light data and proved that panel data analysis could provide a series of regression models to model $\mathrm{CO}_{2}$ emissions efficiently across spatial and temporal dimensions without any ancillary data [36]. Therefore, based on the predecessors' studies, the cargo throughputs of the coastal ports in China are estimated using the panel model and DMSP-OLS night light data.

\section{Materials and Methods}

\subsection{Study Area}

Based on the rankings of Chinese ports in multiple years and data from the China Ports Yearbook, this study selected 28 top ranking coastal ports with active transportation activities among the five major port groups, i.e., the Round Bohai Sea Area Port Group (RBAPG): Dalian Port, Yingkou Port, Jinzhou-Huludao Port, Tianjin Port, Qinhuangdao Port, Tangshan Port, Qingdao Port, Yantai Port, Rizhao Port, and Weihai Port; the Yangtze River Delta Port Group (YRDPG): Shanghai Port, Ningbo-Zhoushan Port, Lianyun Port, Wenzhou Port, Nantong Port, Taizhou Port, and Jiaxing Port; the Southeast Coastal Port Group (SECPG): Xiamen Port and Fuzhou Port; the Pearl River Delta Port Group (PRDPG): Guangzhou Port, Shenzhen Port, Zhuhai Port, Shantou Port, Shanwei Port, and Maoming Port; and the Southwest Coastal Port Group (SWCPG): Zhanjiang Port, Haikou Port, and Sanya Port. Due to the small number of ports selected from the SECPG and SWCP, this paper combined these two port groups with the YRDPG and PRDPG, respectively, so as to ensure sufficient sample sizes and make the panel analysis more accurate. The selected 28 Chinese coastal ports are all among the top 50 global ports. The geographical distribution and spatial temporal change of Cargo Handling Capacity of the 28 coastal ports are shown in Figures 1 and 2.

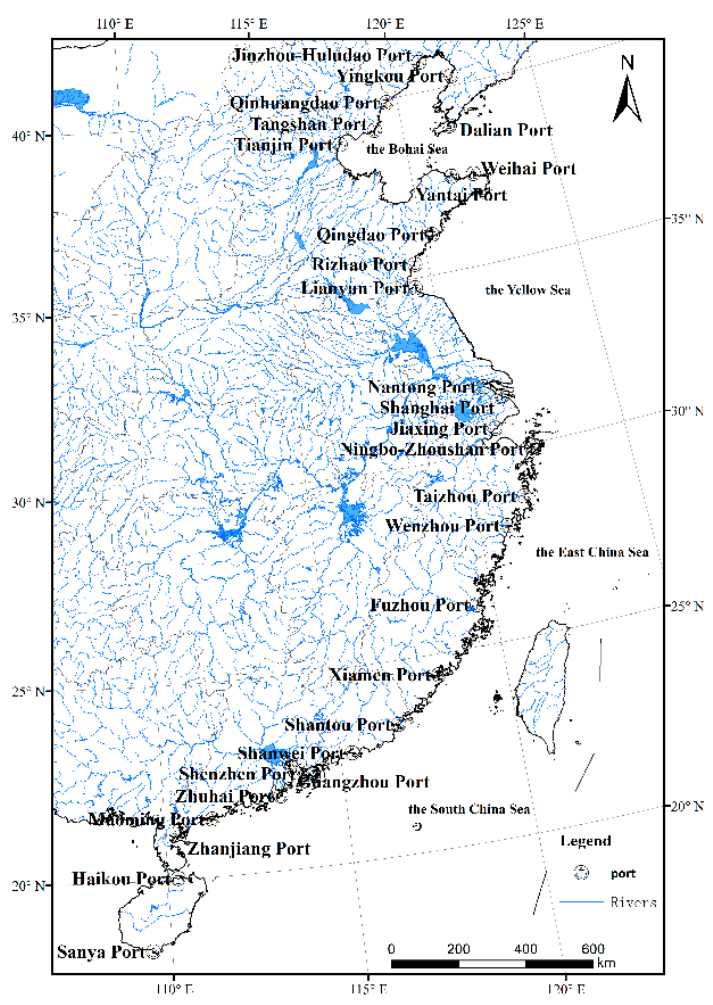

Figure 1. Research cases: the 28 coastal ports in China. 


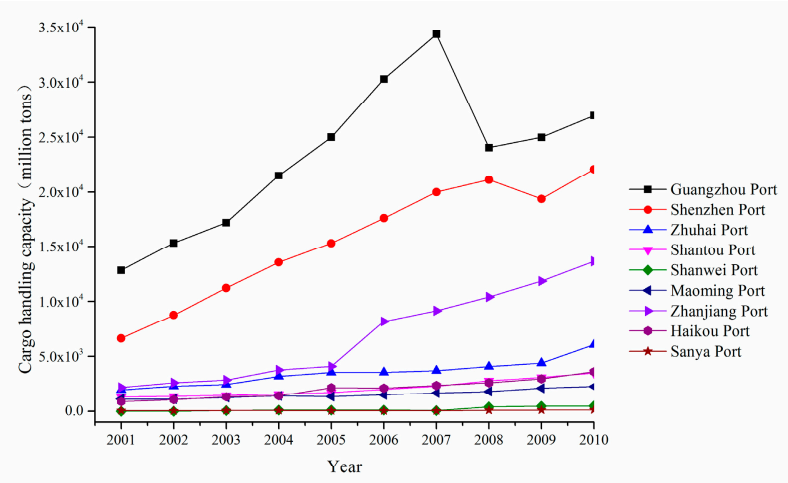

(a)

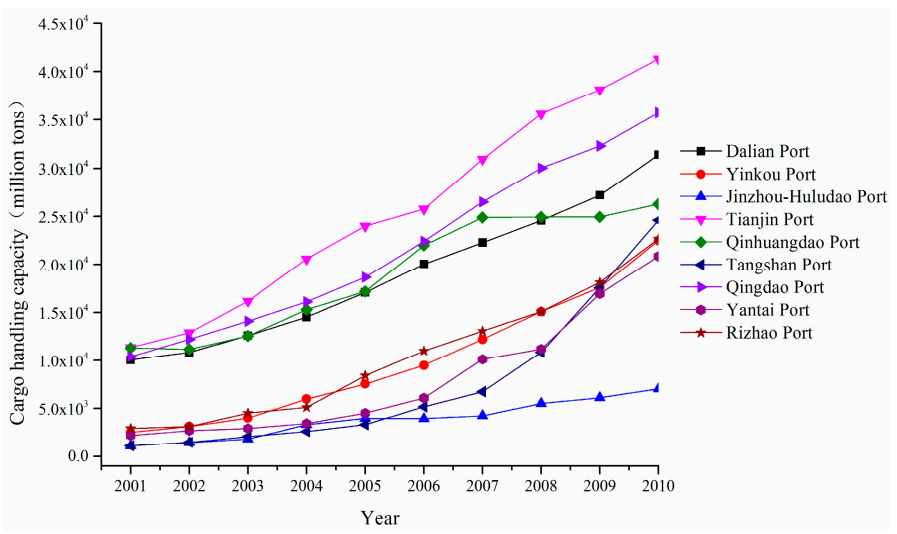

(b)

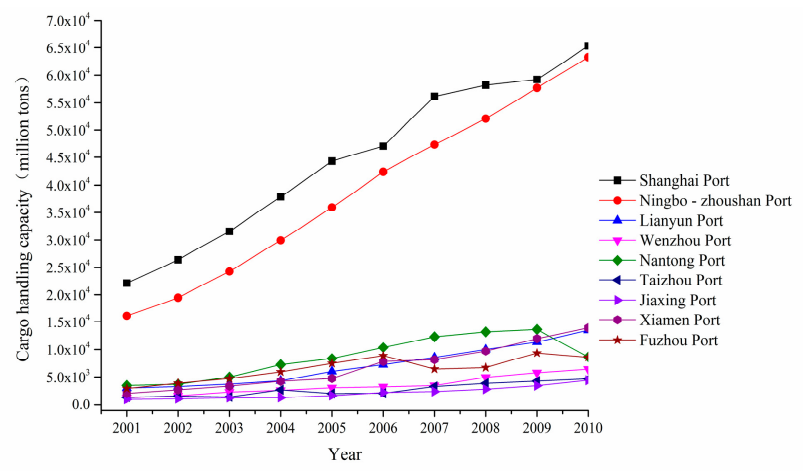

(c)

Figure 2. The Cargo handling capacity of coastal ports in each port group from 2001 to 2010: (a) cargo handling capacity of coastal ports in the RBAPG from 2001 to 2010; (b) cargo handling capacity of coastal ports in the YRDPG \& SECPG from 2001 to 2010; (c) cargo handling capacity of coastal ports in the PRDPG \& SWCPG from 2001 to 2010.

\subsection{Data Source}

This study sorted out the annual cargo handling capacity (in multiples of 10,000 tons) of 28 Chinese coastal ports from the China Ports Yearbook 2001-2013. The 10-year cargo handling capacity data from 2001 to 2010 were used as sample data for modeling, and the 3-year data of 2011, 2012, and 2013 were used to validate the final panel model. 
The DMSP-OLS nighttime average lights (NAL) X Pct data from 2001 to 2013 used in this study was derived from the website of the National Geophysical Data Center (NGDC) of the National Oceanic and Atmospheric Administration (NOAA) (https://ngdc.noaa.gov/eog/dmsp/downloadV4composites. $\mathrm{html}$ ). The DMSP-OLS data downloaded from the NOAA official website was in three formats, i.e., cf_cvg, avg_vis, and stable_light.avg_vis, corresponding to cloud-free observation light frequency image, average DN value image, and stable light $\mathrm{DN}$ value image. This study mainly utilized DMSP-OLS NAL $x$ Pct data. The avg_lights_x_pct is derived from the average visible band digital number $(\mathrm{DN})$ of cloud-free light detections multiplied by the percent frequency of light detection. The inclusion of the percent frequency of detection term normalizes the resulting digital values for variations in the persistence of lighting. For instance, the value for a light only detected half the time is discounted by $50 \%$. Note that this product contains detections from fires and a variable amount of background noise. This is the product used to infer gas flaring volumes from the nighttime lights (https://ngdc.noaa.gov/eog/dmsp/downloadV4composites.html). A series of pre-processing was then performed on the light image.

\subsection{Data Pre-Processing}

First, the latitude and longitude of each port location were collected, and ArcGIS 10.2 software was used to locate the corresponding spatial positions to ensure the accuracy of each port location. However, due to improper planar projection during the research process, it is possible that there is large-scale deformation of the coastal port area on the map, resulting in inconsistency between the real and actual influence range of each port. This also affects the corresponding nighttime light intensity and total cargo handling capacity in the port area and may lead to large errors in research results. In order to avoid this problem, projection transformation was conducted on each port using the ArcGIS software. Since the distances between the ports are relatively small, the projection transformation set the central meridian of Albers projection as the longitude of each port location, respectively. These two operations can effectively reduce the error in nighttime light intensity and increase the accuracy and precision of the data in this research.

Due to such reasons as the angular deviation of each flight of the DMSP satellites and the continuous aging of the OLS sensors, mechanical errors in images have increased every year. Therefore, it is necessary to compensate for these errors through inter-calibration of images. Elvidge et al. suggested using the areas having very little change in light over time (also known as Pseudo Invariant Features, PIFs [37]) and second order regression model to address this issue [38]. The key to the method is to find the appropriate reference image and PIFs. In terms of the reference image, they pointed out that the satellite data image F12 1999 has the highest saturation value of light intensity, and the urban bright center in this remote-sensing image has the highest saturation value $(\mathrm{DN}=63)$ [38]. In terms of PIFs, of all the areas examined, Sicily had the most favorable characteristics-an even spread of data across the full dynamic range and a more sharply defined diagonal clusters of points. Thus, taking all the pixels within Sicily as PIFs and F12 1999 as a reference image, the nighttime light grid data for 13 years from 2001 to 2013 were intercalibrated by using the second order regression model according to Elvidge et al. [38]. Figure 3 shows the scatter plots for each of the satellite years versus F12 1999 for the nighttime lights of Sicily. 


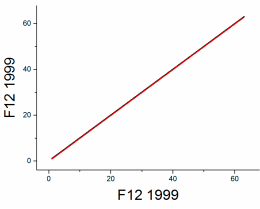

F12 1999

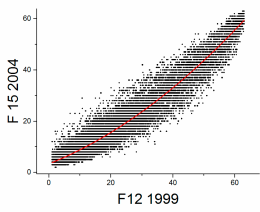

F15 2004

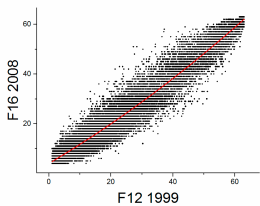

F16 2008

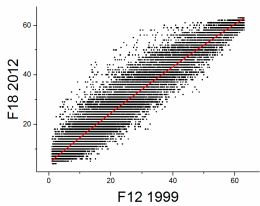

F18 2012

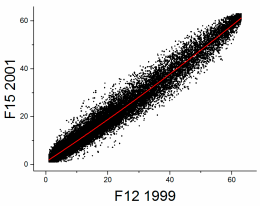

F15 2001

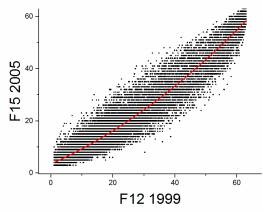

F15 2005

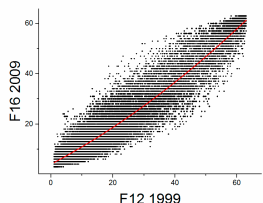

F16 2009

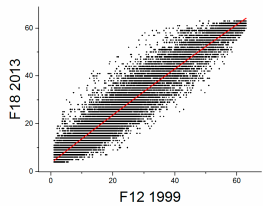

F18 2013

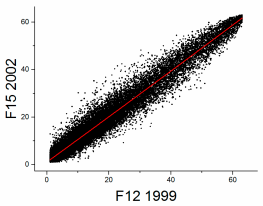

F15 2002

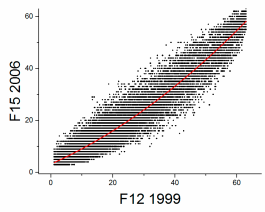

F15 2006

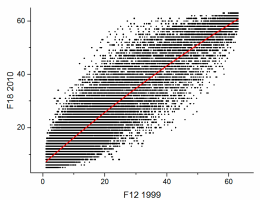

F18 2010

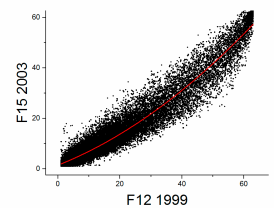

F15 2003

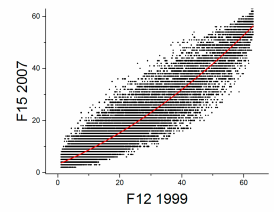

F15 2007

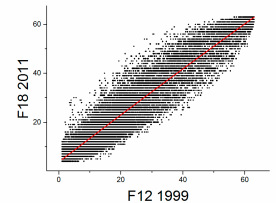

F18 2011

Figure 3. Scatter plot for image calibration for each year.

\subsection{Generation of the Port Buffer Zone and Statistics of Light Values}

The spatial range needs to be determined before the statistical analysis of light values. First, it is necessary to obtain the spatial position of each port and then establish a buffer zone centered on this position. The buffer zone is regarded as the main transportation activity area of the port, i.e., the statistical range of the light values. Too small a buffer zone may cause incomplete coverage, while too large a buffer zone may overlap with the activity area of an adjacent port, which will make it impossible to clearly distinguish the light intensity contributions of each port in the overlapping area. In order to ensure that there is no overlap between the buffer areas of the two closest ports, Shenzhen port and Guangzhou port, and ensure all the buffer areas can cover all the lights near each port, we selected $22.2 \mathrm{~km}$ as the buffer radius. It seems more reasonable that the appropriate buffer zones should be determined according to the port size, but doing this requires more prior knowledge. In this sense, a fixed radius is more appropriate and makes the method more generally applicable. The 28 ports selected in this paper are all coastal ports. The Port of Hong Kong is not included in the study area since it is too close to the surrounding ports. Despite some cargo transportation, and the loading and unloading activities on land, most of their activities such as cargo transportation and shipping are completed at sea. Because some irrelevant urban activities on land such as the living, working and entertainment of city residents have a greater impact on light intensity, the land lights should be excluded from the buffer zones when estimating cargo handling capacity. To address this issue, the pixels located over land were identified by using the latest administrative map provided by the Ministry of Civil Affairs of the People's Republic of China (http:/ /xzqh.mca.gov.cn/map) and excluded from the analysis. The specific range of each port buffer zone is shown in Figure 4. 
After determining the effective range of the port buffer zone, statistics were prepared for the total light values in each buffer zone.

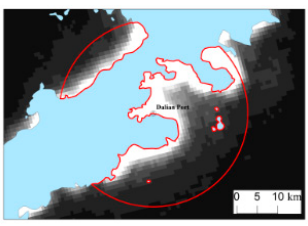

Dalian Port

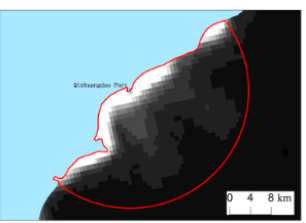

Qinhuangdao Port

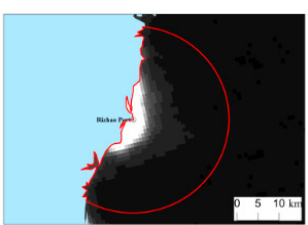

Rizhao Port

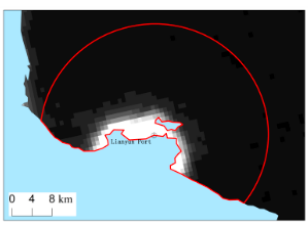

Lianyun Port

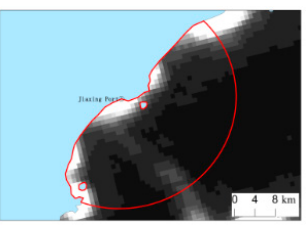

Jiaxing Port

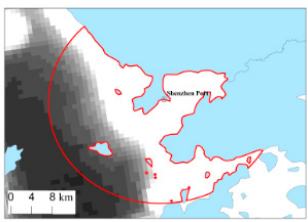

Shenzhen Port

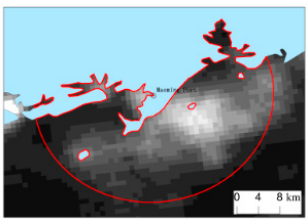

Maoming Port

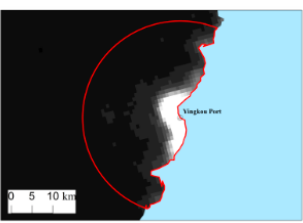

Yingkou Port

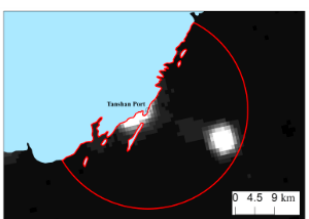

Tangshan Port

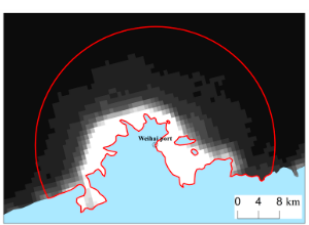

Weihai Port

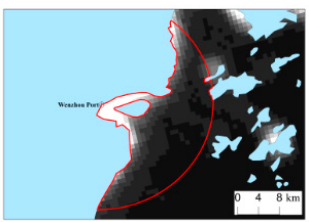

Wenzhou Port

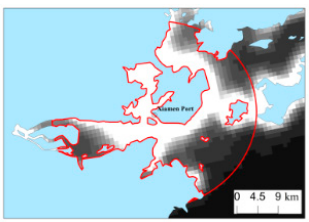

Xiamen Port

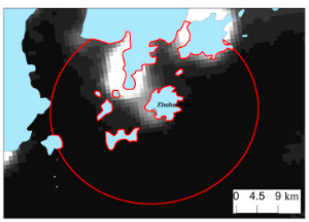

Zhuhai Port

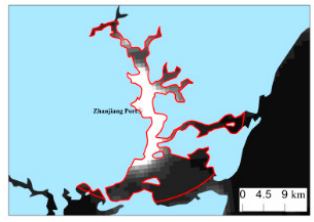

Zhanjiang Port

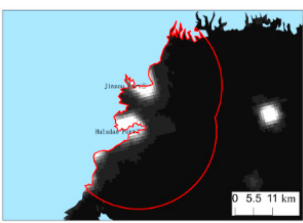

Jinzhou-Huludao Port

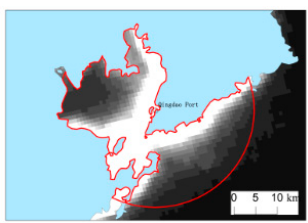

Qingdao Port

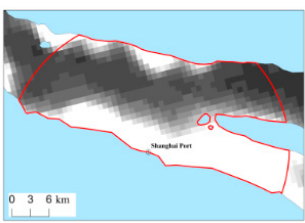

Shanghai Port

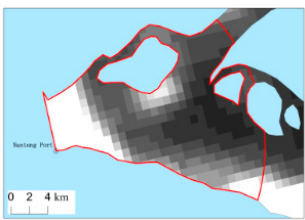

Nantong Port

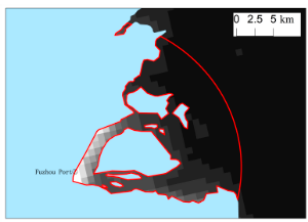

Fuzhou Port

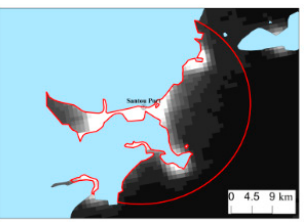

Shantou Port

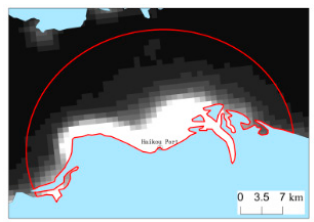

Haikou Port

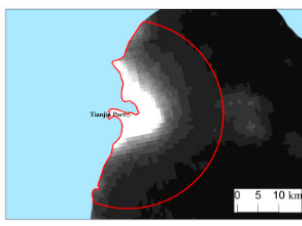

Tianjin Port

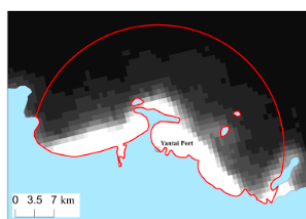

Yantai Port

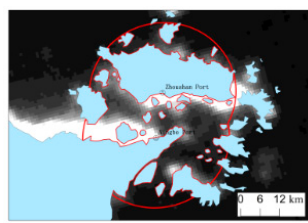

Ningbo-Zhoushan Port

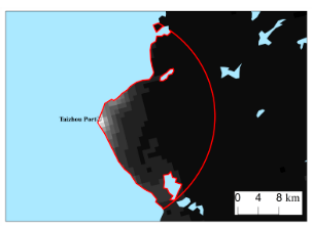

Taizhou Port

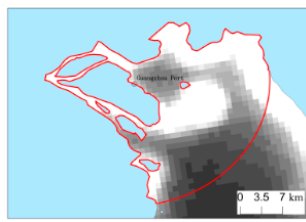

Guangzhou Port

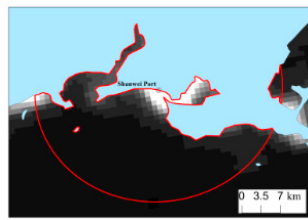

Shanwei Port

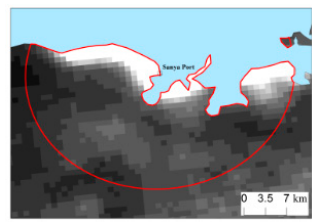

Sanya Port

Figure 4. Light collection range of coastal ports. 


\subsection{Establishment of Panel Model}

Both time-series data and cross-section data are one-dimensional. Time-series data are data of a variable derived over time, and cross-section data are a data set of a variable at a fixed time point. The panel data are two-dimensional data composed of both time-series and cross-section data. They are the repeated observation data of the individual entity on the cross section at different time points. From the cross-sectional view, the panel data are composed of cross-sectional observation values of several individual entities at a certain time point. From the longitudinal-sectional perspective, each individual entity is a time series.

Previously, scholars tended to use time series to study the cargo handling capacity of ports. For instance, Adhikari proposes a linear combination method for the prediction of port cargo handling capacity based on time series [39]. Recently, many scholars have taken advantage of panel data in research, such as a using panel data model to simulate the efficiency of ports operating (cargo) in Europe [40] and using panel data model to estimate the transportation demand of perishable cargo [41]. This study used the panel model to establish a regression relationship between the cargo handling capacity $(\mathrm{CHC})$ and the nighttime average lights (NAL) of coastal ports.

\subsubsection{Unit Root Test of Panel Data}

Some non-stationary time series often show a common variation trend. However, these time series are not necessarily directly correlated. Although the regression of such data may produce a high $\mathrm{R}$-squared value, the result may have no practical significance. In order to avoid spurious regression and ensure the validity of estimation results, it is necessary to test the stationarity of each panel data [42]. In general, the stationarity of times series can be roughly judged by some attribute graphs of the series. However, the result of this visual inspection may be inaccurate. Hence, the most common method, i.e., the unit root test, was used to test the stationarity of the data. The null hypothesis of the unit root test assumes that the data are non-stationary; if the test results reject the null hypothesis, the data are stationary. The unit root test method has become an important basis for the complex analysis of panel analysis. Two specific methods, namely Levin-Lin-Chu (LLC) test [43] and the Augmented Dickey Fuller-Fisher test [44], are commonly used for the unit root test and for authenticating each other.

\subsubsection{Co-Integration Test of Panel Data}

If the unit root test finds that the variables in the same order are integrated, then the co-integration test can be continued to further avoid spurious regression and prove that there is a long-term equilibrium relationship among these series at the statistical level. The null hypothesis of the co-integration test assumes that there is no co-integration relationship between the variables. If the test results do not reject the null hypothesis, there may be no long-term relationship between the variables, and the resulting panel model cannot be used to estimate the predicted values. Pedroni proposed seven commonly used methods of panel co-integration tests based on residuals under null hypothesis, namely, panel v-statistic, panel rho-statistic, panel PP-statistic, panel ADF-statistic, group rho-statistic, group PP-statistic, and group ADF-statistic [45]. Such methods allow for the existence of a heterogeneous panel. Thus, we used these methods to preform co-integration tests. Detailed descriptions of these tests and related thresholds can be discovered in Pedroni's papers [46].

\subsubsection{Panel Model Estimation}

The sample data used in panel estimation contained information in three aspects, i.e., individual entity, indicator, and time. If the model form is incorrectly set, the estimation result will deviate far from the desired simulation. Generally, there are three panel data models, i.e., the constant coefficient model, the variable intercept model, and the variable parameter model.

$$
y_{i t}=\alpha+x_{i t} \cdot \beta+\varepsilon_{i t}, \quad(i=1,2, \ldots, N ; t=1,2, \ldots, T) .
$$


Case 1: $\alpha_{i}=\alpha_{j}, \beta_{i}=\beta_{j}$ (constant coefficient model);

Case 2: $\alpha_{i} \neq \alpha_{j}, \beta_{i}=\beta_{j}$ (variable intercept model);

Case 3: $\alpha_{i} \neq \alpha_{j}, \beta_{i} \neq \beta_{j}$ (variable parameter model).

As a consequence, the first step in building a panel model is to determine which model form the sample data conforms to, so as to avoid deviations in model settings and improve the validity of parameter estimation. The following two hypotheses are mainly tested:

$$
\begin{gathered}
H_{1}: \beta_{1}=\beta_{2}=\ldots=\beta_{N} \\
H_{2}: \alpha_{1}=\alpha_{2}=\ldots=\alpha_{N}, \quad \beta_{1}=\beta_{2}=\ldots=\beta_{N} .
\end{gathered}
$$

If the hypothesis $\mathrm{H}_{2}$ is accepted, the constant coefficient model is considered as the model that matches the sample data. If the hypothesis $\mathrm{H}_{2}$ is rejected, and hypothesis $\mathrm{H}_{1}$ is accepted, the variable intercept model is considered as the model that matches the sample data. If both, hypothesis $\mathrm{H}_{1}$ and hypothesis $\mathrm{H}_{2}$ are rejected, the variable parameter model is considered as the model that matches the sample data. This study mainly used the F-test to determine the rational panel model.

The technical procedure of the entire research is as follows (Figure 5). First, we selected and downloaded the required data, then performed inter-calibration of the DMSP-OLS data and projection adjustment of the vector data. Secondly, the total light intensity of the sea area in the buffer zone of each coastal port in the calibrated image was obtained. Thirdly, the panel data for unit root test and co-integration test were prepared to obtain the optimal panel model. Finally, the panel model was verified.

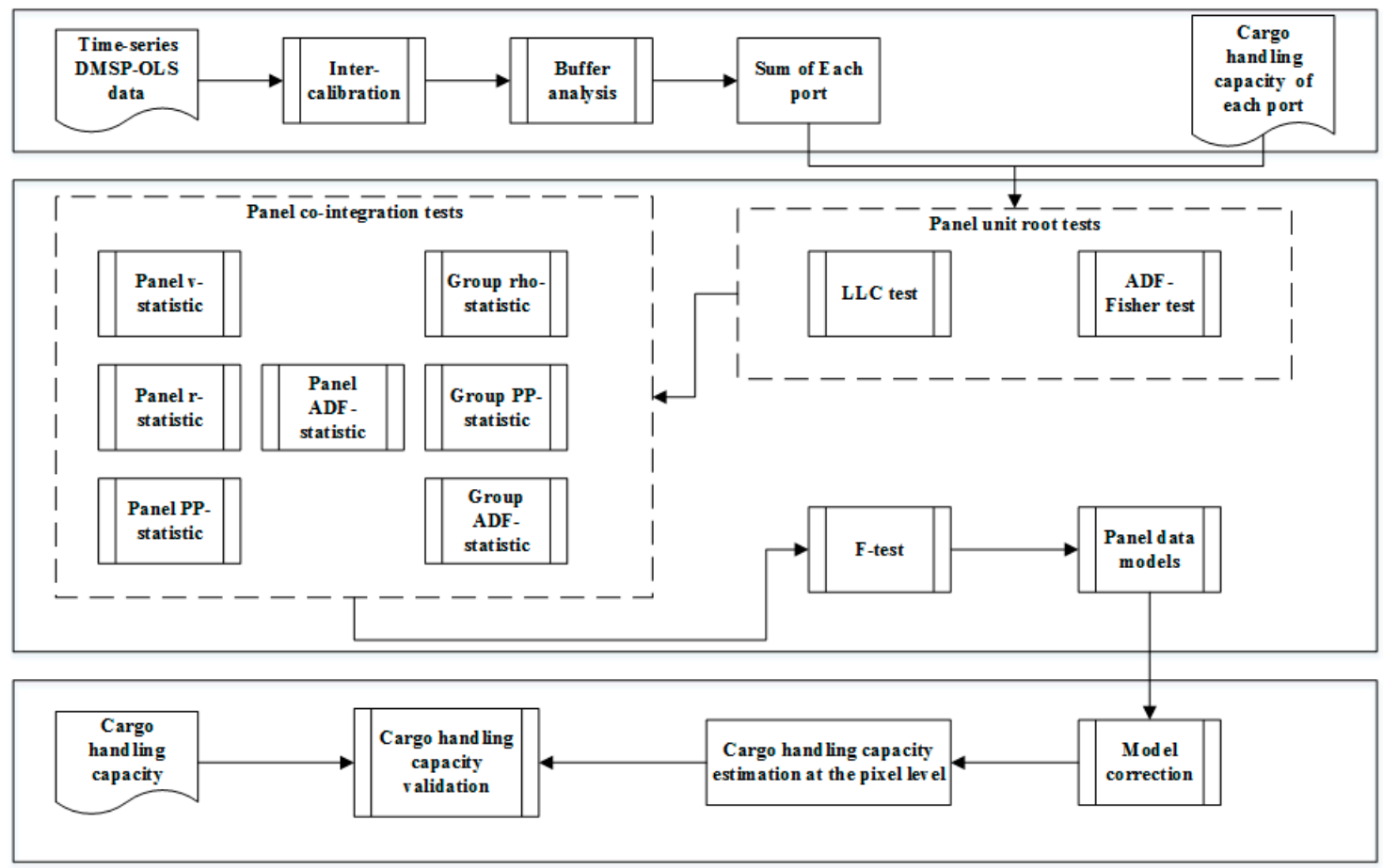

Figure 5. Research process flow chart.

\section{Results}

The study was conducted at two spatial scales, i.e., three port groups and 28 ports, and the corresponding panel model parameters were obtained to estimate the cargo handling capacity and carry out spatiotemporal dynamic analysis. 


\subsection{Results of Unit Root Test of Panel Data}

In this study, the Levin-Lin-Chu (LLC) test and the ADF-Fisher test were used for the unit root test of CHC and the DMSP-OLS NAL of the following port groups: the RBAPG, the YRDPG \& SECPG, and the PRDPG \& SWCPG. Table 1 shows the test results. On the whole, the levels of CHC and NAL in the RBAPG, the YRDPG \& SECPG, and the PRDPG \& SWCPG showed unstable test results in the LLC test and ADF test, rejecting the null hypothesis at the 1,5, and 10\% significance levels, or even not rejecting the null hypothesis. In the next first-difference transformation, almost all CHC and NAL passed the LLC test and ADF test at the $1 \%$ significance level, rejecting the non-stationary null hypothesis. It is thus proved that both CHC and NAL are stationary variables, ruling out spurious regression to some extent.

Table 1. Pool unit root test.

\begin{tabular}{cccccc}
\hline Port Group & Variable & ADF & ADF & LLC & LLC \\
\hline \multirow{2}{*}{ RBAPG } & & Level & First Difference & Level & First Difference \\
\hline \multirow{2}{*}{ YRDPG \& SECPG } & CHC & 11.8788 & $42.5880^{* * *}$ & 1.11674 & $-8.35618^{* * *}$ \\
& NAL & $34.9262^{* *}$ & $71.2847^{* * *}$ & $-11.8514^{* * *}$ & $-12.2575^{* * *}$ \\
PRDPG \& SWCPG & NAL & 17.33534 & 24.1933 & $-1.64247^{* *}$ & $-4.75277^{* * *}$ \\
& CHC & $3.61234^{*}$ & $23.2828^{* * *}$ & $-4.28212^{* * *}$ & $-6.69991^{* * *}$ \\
& NAL & 23.6416 & $33.1364^{* * *}$ & 4.31733 & $-4.81040^{* * *}$ \\
\hline
\end{tabular}

* Significant at the $10 \%$ level; ** significant at the $5 \%$ level; *** significant at the $1 \%$ level.

\subsection{Results of the Co-Integration Test of Panel Data}

At the spatial scale of port groups, the co-integration test was conducted on two indicators of the three port groups. Table 2 shows that the results of the five test methods for the RBAPG and the PRDPG \& SWCPG rejected the null hypothesis, and the results of the three test methods for the YRDPG \& SECPG rejected the null hypothesis. In the panel PP-statistic method, all three port groups rejected the null hypothesis of non-cointegration at the $1 \%$ significance level. It can be seen that there is a long-term equilibrium relationship between CHC and NAL in the three port groups, which can completely rule out the case that the regression is spurious. The functional relationship between $\mathrm{CHC}$ and NAL is meaningful [47].

Table 2. Results of panel co-integration tests.

\begin{tabular}{|c|c|c|c|c|c|c|c|}
\hline Port Group & $\begin{array}{c}\text { Panel } \\
\text { v-Statistic }\end{array}$ & $\begin{array}{c}\text { Panel } \\
\text { rho-Statistic }\end{array}$ & $\begin{array}{c}\text { Panel } \\
\text { PP-Statistic }\end{array}$ & $\begin{array}{c}\text { Panel } \\
\text { ADF-Statistic }\end{array}$ & $\begin{array}{c}\text { Group } \\
\text { rho-Statistic }\end{array}$ & $\begin{array}{c}\text { Group } \\
\text { PP-Statistic }\end{array}$ & $\begin{array}{c}\text { Group } \\
\text { ADF-Statistic }\end{array}$ \\
\hline RBAPG & -0.902304 & 0.705141 & $-5.877560 * * *$ & $-2.594381^{* * *}$ & 2.137482 & $-9.447249 * * *$ & $-3.073088^{* * *}$ \\
\hline YRDPG \& SECPG & $3.448060^{* * *}$ & $-2.467861^{* * *}$ & $-4.330827^{* * *}$ & 0.403685 & 0.809806 & -0.960831 & 0.814878 \\
\hline PRDPG \& SWCPG & $3.966106^{* * *}$ & 0.335334 & $-8.996168^{* * *}$ & $-3.608918^{* * * *}$ & 1.950330 & $-7.409503^{* * * *}$ & $-3.075394^{* * *}$ \\
\hline
\end{tabular}

\subsection{Parameter Estimation of the Panel Model}

After multiple attempts, the variable parameter panel model passed the F test and was the most suitable for capturing the regression relationship between CHC and NAL. The R-squared, adjusted R-squared, F-statistic, and Prob (F-statistic) parameters of the model are shown in Table 3. The variable parameter model can adapt to complex actual changes, reduce deviations, and improve accuracy. Therefore, the variable parameter model is widely used and plays an important role in the fields of biology, medicine, environment, finance, etc. [48]. The variable parameter panel model was used for modeling CHC and NAL in this study. The derived model at the port group level is as follows:

RBAPG:

$$
\mathrm{CHC}_{i t}=-100017.9661066+\alpha_{i}+\beta_{i} N A L_{i t} \quad(i=1,2, \ldots, 10 ; t=1,2, \ldots, 10) .
$$


YRDPG \& SECPG:

$$
\mathrm{CHC}_{i t}=-10522.7043291+\alpha_{i}+\beta_{i} N A L_{i t} \quad(i=1,2, \ldots, 9 ; t=1,2, \ldots, 10)
$$

PRDPG \& SWCPG:

$$
\mathrm{CHC}_{i t}=-10190.8948633+\alpha_{i}+\beta_{i} N A L_{i t} \quad(i=1,2, \ldots, 9 ; t=1,2, \ldots, 10) .
$$

Table 3. Model parameters of port groups.

\begin{tabular}{ccccc}
\hline Port Group & R-Squared & Adjusted R-Squared & F-Statistic & Prob (F-Statistic) \\
\hline RBAPG & 0.873629 & 0.843616 & 29.10834 & 0.000000 \\
YRDPG \& SECPG & 0.978657 & 0.973618 & 794.2081 & 0.000000 \\
PRDPG \& SWCPG & 0.927828 & 0.910787 & 54.44777 & 0.000000 \\
\hline
\end{tabular}

Table 4 are models derived at the port level. It can be seen from Table 4 that the CHC and NAL of 27 ports are obviously positively correlated. Only in Maoming Port is the coefficient $\beta_{i}$ negative, showing a negative correlation with NAL, but its intercept $\alpha_{i}$ is very large. The case of Maoming Port is worth further exploration.

\begin{tabular}{|c|c|c|c|}
\hline Port Group & Port & $\beta_{i}$ & $\alpha_{i}$ \\
\hline \multirow{10}{*}{ RBAPG } & Dalian Port & 2.97316480967 & $-29,800.8460021$ \\
\hline & Yingkou Port & 1.51259165806 & $10,139.6909277$ \\
\hline & Jinzhou Port & 1.08230668582 & 9611.7506492 \\
\hline & Tianjin Port & 2.28021081738 & 8339.30420347 \\
\hline & Qinhuangdao Port & 2.93348582808 & $14,313.2481409$ \\
\hline & Tangshan Port & 4.35352549308 & 5723.6833558 \\
\hline & Qingdao Port & 2.69021227798 & $-34,697.1797607$ \\
\hline & Yantai Port & 1.44303547357 & 1888.39510679 \\
\hline & Rizhao Port & 3.54326127447 & 5922.03727201 \\
\hline & Weihai Port & 0.365999992386 & 8559.91610698 \\
\hline \multirow{9}{*}{ YRDPG \& SECPG } & Shanghai Port & 5.30720435849 & $-38,838.5697443$ \\
\hline & Ningbo-Zhoushan Port & 2.34490630312 & $10,038.0934431$ \\
\hline & Lianyun Port & 3.49366796774 & 6480.15261962 \\
\hline & Wenzhou Port & 2.40333674731 & 7381.84050485 \\
\hline & Nantong Port & 1.66437462899 & $12,547.3393606$ \\
\hline & Taizhou Port & 1.90768606351 & $11,490.8742163$ \\
\hline & Jiaxing Port & 0.668939673475 & 9850.14836242 \\
\hline & Xiamen Port & 2.37719613324 & $-31,316.9531034$ \\
\hline & Fuzhou Port & 5.46452736258 & $12,367.0743408$ \\
\hline \multirow{9}{*}{ PRDPG \& SWCPG } & Guangzhou Port & 1.43838402662 & $12,127.2906713$ \\
\hline & Shenzhen Port & 2.57695331345 & $-45,905.6297616$ \\
\hline & Zhuhai Port & 0.538321113604 & 9563.65544466 \\
\hline & Shantou Port & 0.699682060439 & 7324.55617453 \\
\hline & Shanwei Port & 0.23474882113 & 8506.50287551 \\
\hline & Maoming Port & -0.130224114145 & $10,683.1372926$ \\
\hline & Zhanjiang Port & 7.1384914425 & $-15,059.5314971$ \\
\hline & Haikou Port & 0.888932009617 & 4145.79490213 \\
\hline & Sanya Port & 0.0291353214443 & 8614.22389788 \\
\hline
\end{tabular}

Table 4. Panel model coefficient $\beta_{i}$ and intercept $\alpha_{i}$ of coastal ports at the port level. 


\subsection{Verification of the Panel Model}

\subsubsection{Accuracy Test for All Ports}

Based on the obtained variable parameter panel model, the $\mathrm{CHC}$ values of each port from 2011 to 2013 were predicted using the NAL data in these three years, and the predicted values were then compared with the real values. Figure 6 compares the real and predicted $\mathrm{CHC}$ in these three years. It can be seen from the figure that the two are very close and almost match perfectly at some ports. Hence, the variable parameter panel model is rational.

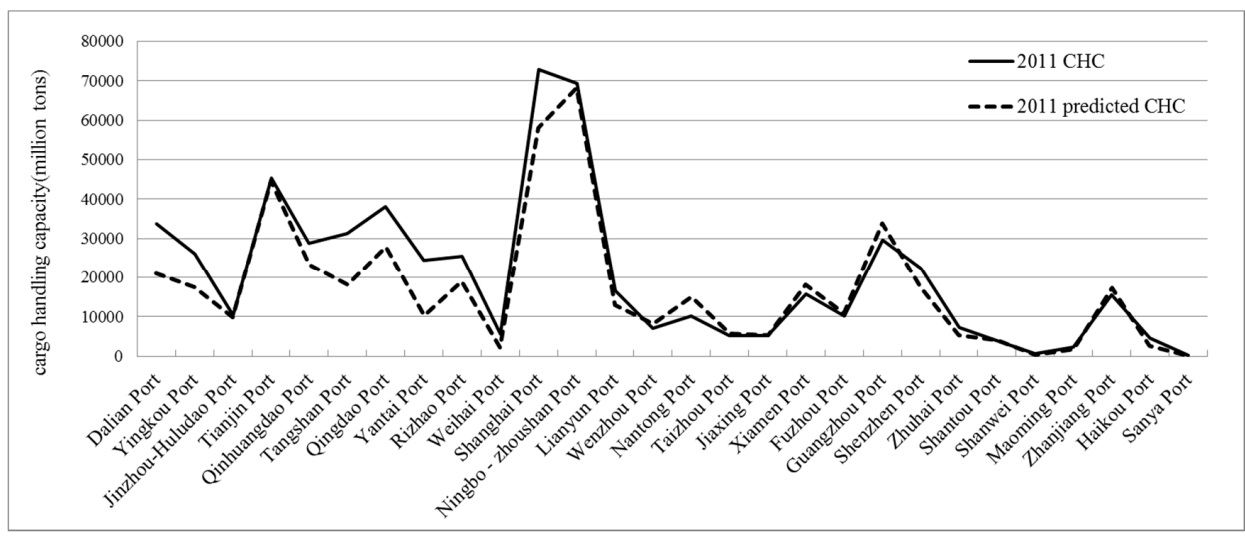

(a)

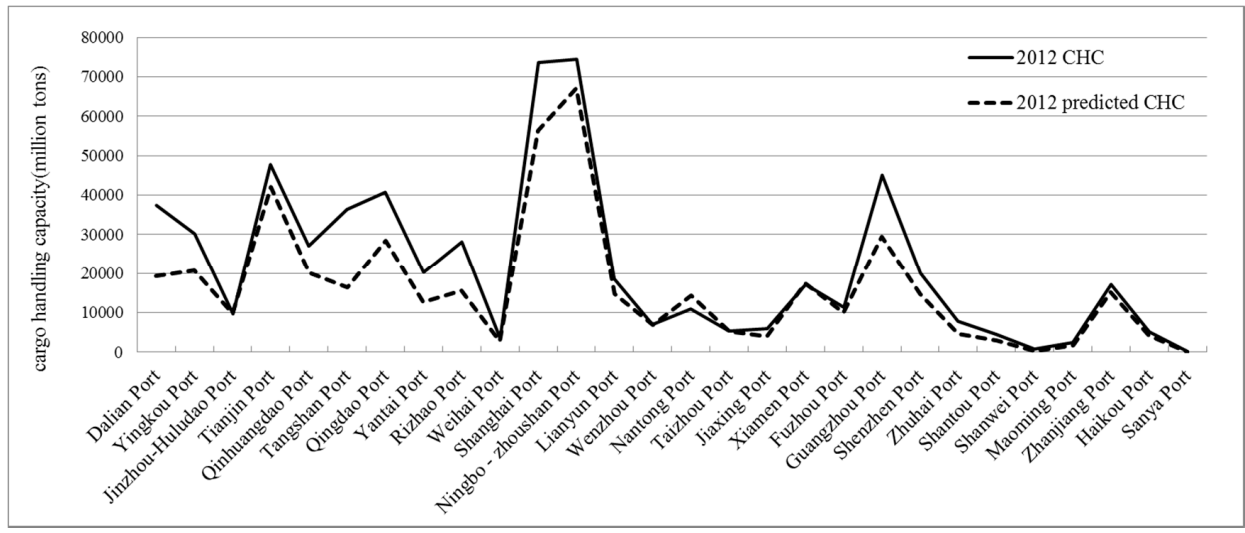

(b)

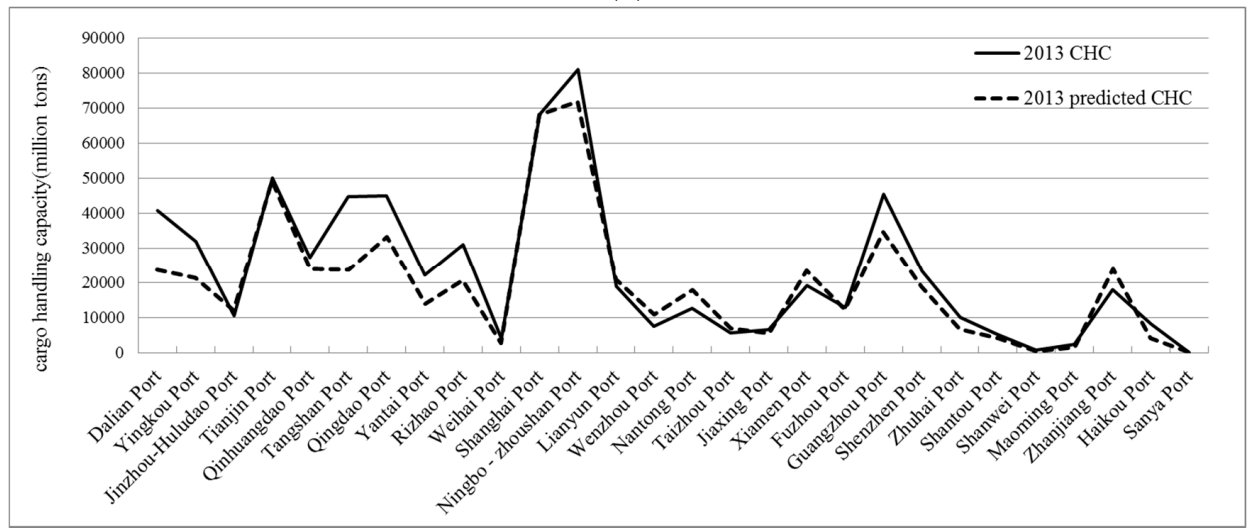

(c)

Figure 6. Comparison between the real and predicted CHC of coastal ports: for the year of 2011, 2012, and 2013: (a) Comparison between real and predicted CHC of coastal ports in 2011; (b) Comparison between real and predicted CHC of coastal ports in 2012; (c) Comparison between real and predicted CHC of coastal ports in 2013. 
In order to further prove the rationality of the variable parameter panel model, a linear regression model was established using the predicted and real values. As shown in Figure 7, the R-square values between real and predicted CHC in these three years were all above 0.9, passing the F-test at the 0.01 significance level. It is again proved that the DMSP-OLS NAL can simulate CHC via the variable parameter panel model.

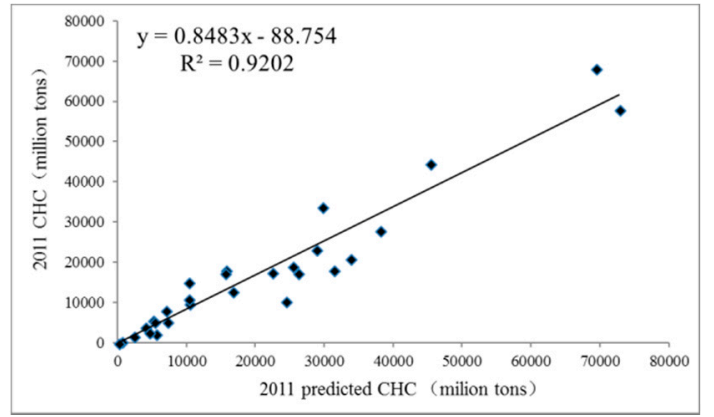

(a)

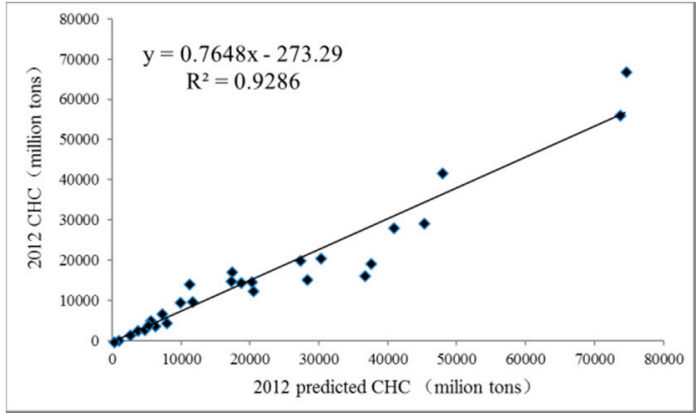

(b)

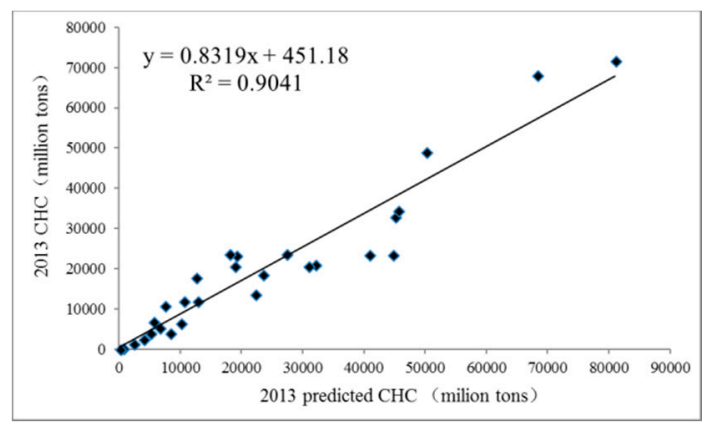

(c)

Figure 7. Fitting degree between real and predicted CHC of coastal ports for the year of 2011, 2012, and 2013: (a) Fitting degree between real and predicted CHC of coastal ports in 2011; (b) Fitting degree between real and predicted CHC of coastal ports in 2012; (c) Fitting degree between real and predicted CHC of coastal ports in 2013.

\subsubsection{Accuracy Test for Three Port Groups}

Figure 8 is a comparison chart of the predicted and real CHC of the three port groups in 2013.

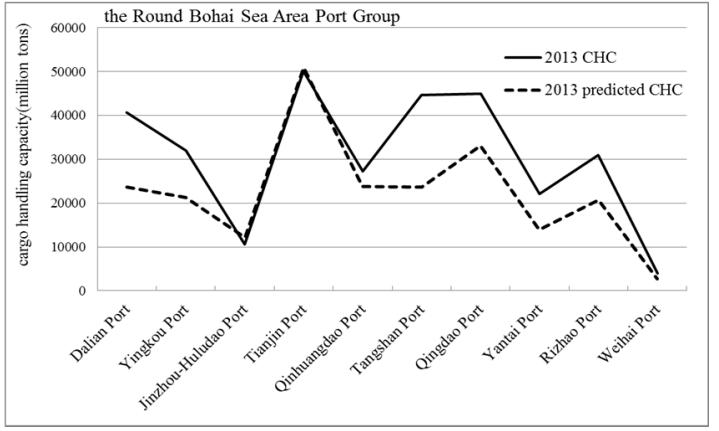

(a)

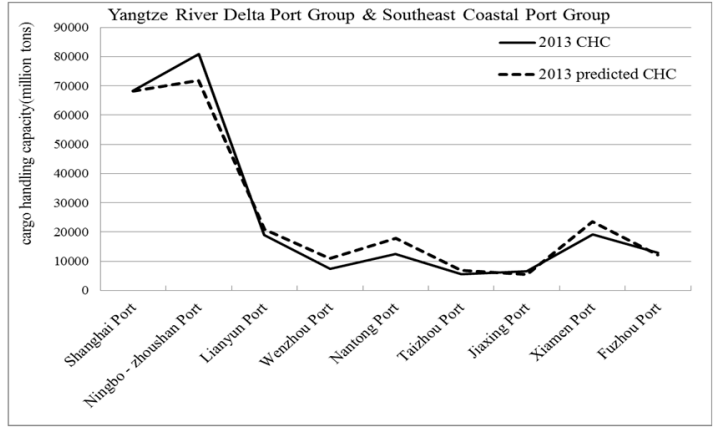

(b)

Figure 8. Cont. 


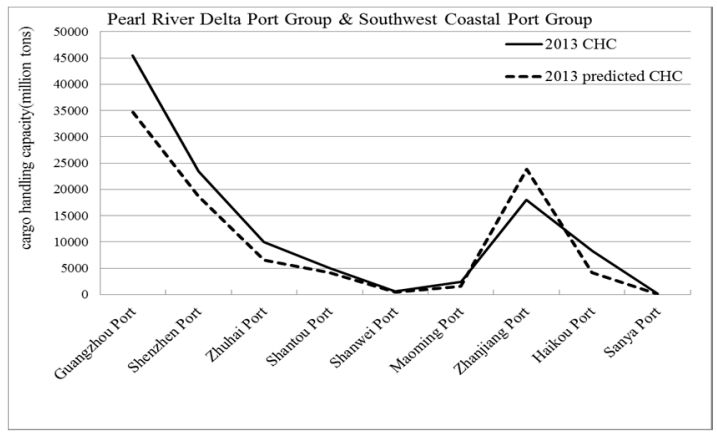

(c)

Figure 8. Fitting degrees at the port group level: (a) fitting degrees of the RBAPG; (b) fitting degrees of the YRDPG \& SECPG; (c) fitting degrees of the PRDPG \& SWCPG.

From Figure 8, it appears that the fitting accuracy of the model has certain geographical differences. The R-square of regression model for the RBAPG was 0.753 , which was significantly lower than 0.985 for the YRDPG \& SECPG and 0.918 for the PRDPG \& SWCPG. We speculated that this may be related to air quality. The heavy haze pollution around the Bohai sea might weaken the light emitted from the ports. To confirm this suspicion, we collected air quality index (AQI) data of 53 coastal cities in 2014 from the China National Environmental Monitoring Center. According to the National Ambient Air Quality Standard of China, AQI is a dimensionless index that quantitatively describes air quality. The bigger the value, the more serious the air pollution situation is. The kriging interpolation method was used to generate an AQI map as shown in Figure 9. As we guessed, the Bohai-Rim area had the most serious air pollution problem, which reduced the intensity of the light. Therefore, the fitting degree of the RBAPG is relatively lower than other port groups in 2013. However, in recent years, China's air quality has improved significantly, so this external factor can be ignored in prediction processes in the future.

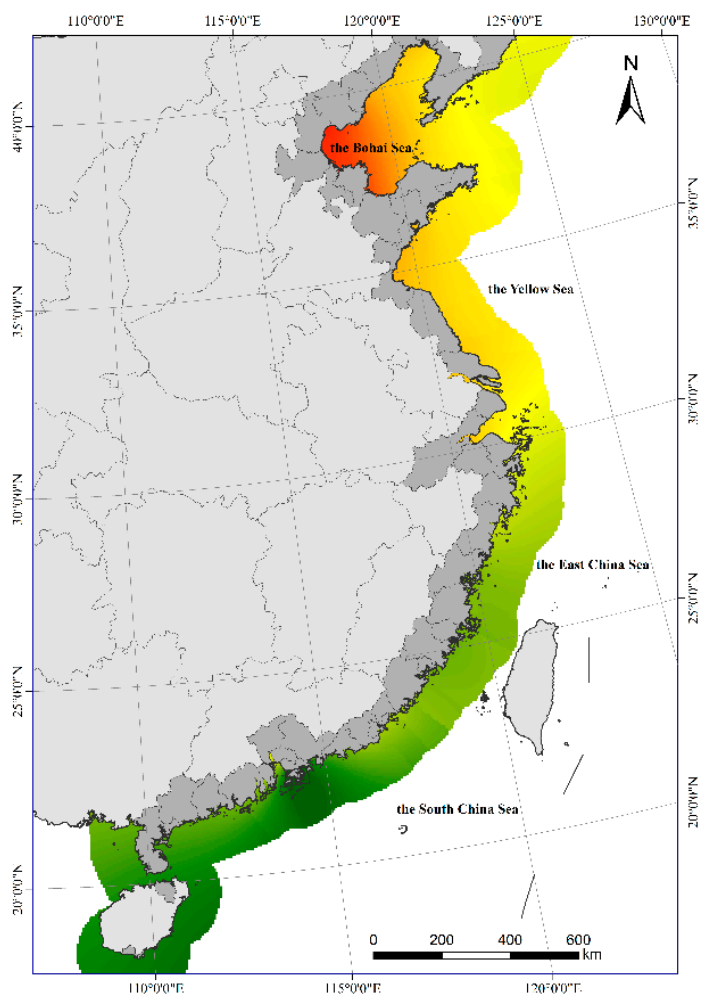

Figure 9. The heat map of the air quality index (AQI) in the coastal area of China in 2014. 


\subsection{Spatial Pattern and Evolution of CHC for Coastal Ports in China from 2001 to 2015}

The above results can be used to analyze the spatial pattern and evolution of $\mathrm{CHC}$ for coastal ports in China and help understand and plan the cargo transportation routes and mechanisms of coastal ports in China. Choosing a right time interval helps to better observe the spatial-temporal change $[49,50]$, thus we investigated the spatial pattern and evolution of $\mathrm{CHC}$ for Coastal Ports at five-year intervals. Figure 10 shows the spatial distribution of $\mathrm{CHC}$ for 28 large coastal ports in China in 2001, 2005, 2010, and 2015. It can be seen from Figure 10 that, in the 15 years from 2001 to 2015, the total CHC of China's coastal ports continued to increase and maintained a generally stable distribution. The coastal ports that always possess a high CHC include Dalian Port, Qinhuangdao Port, Tianjin Port, Qingdao Port, Shanghai Port, Ningbo-Zhoushan Port, Guangzhou Port, and Shenzhen Port. The CHC of Shanghai Port always ranked first in China, and Ningbo-Zhoushan Port ranked second. The gap between the two has rapidly narrowed since 2010. From 2005 to 2010, the overall $\mathrm{CHC}$ of 28 ports increased rapidly, and the growth rate slowed down from 2010 to 2015. Yingkou Port, Tangshan Port, Yantai Port, and Rizhao Port began to grow after 2005, with CHC increasing year by year. The CHC of Xiamen Port and Wenzhou Port also increased rapidly after 2010. In 2001, the CHC of Maoming Port and Zhanjiang Port were evenly matched, but in 2015, the CHC of Zhanjiang Port far exceeded that of Maoming Port. It is worth noting that, due to the tightening of resource export policy and the implementation of energy security strategy in 2005, the growth rate in this year was not particularly significant compared with that in 2001.

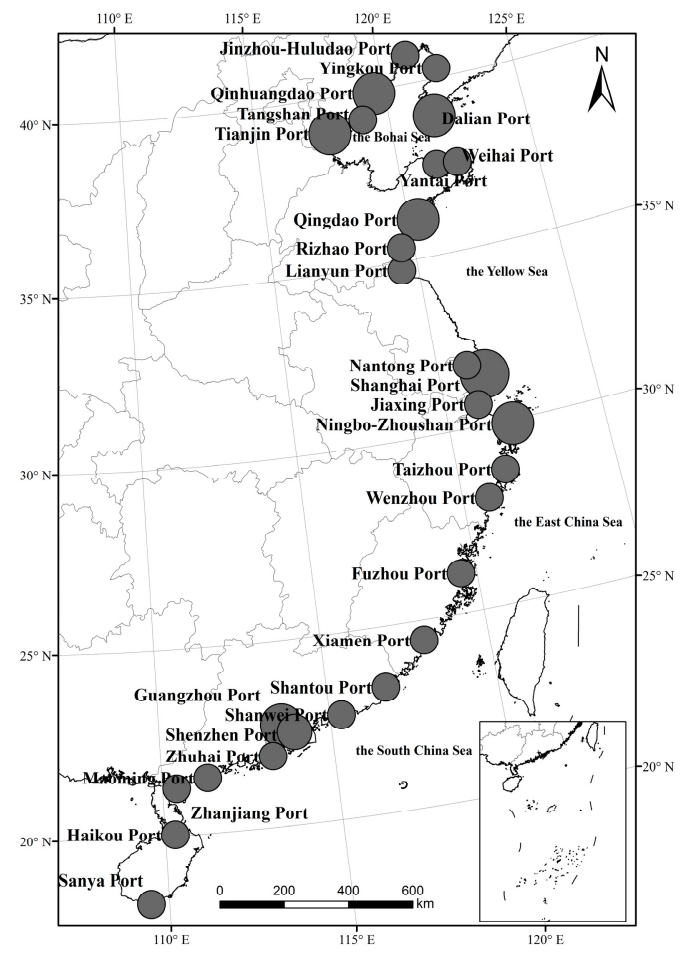

(a)

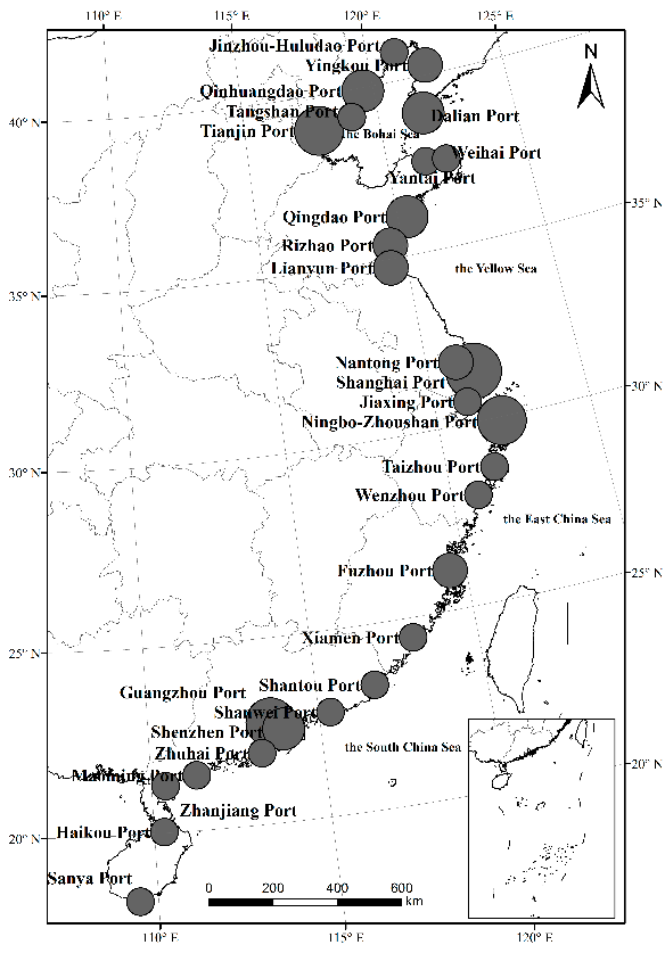

(b)

Figure 10. Cont. 


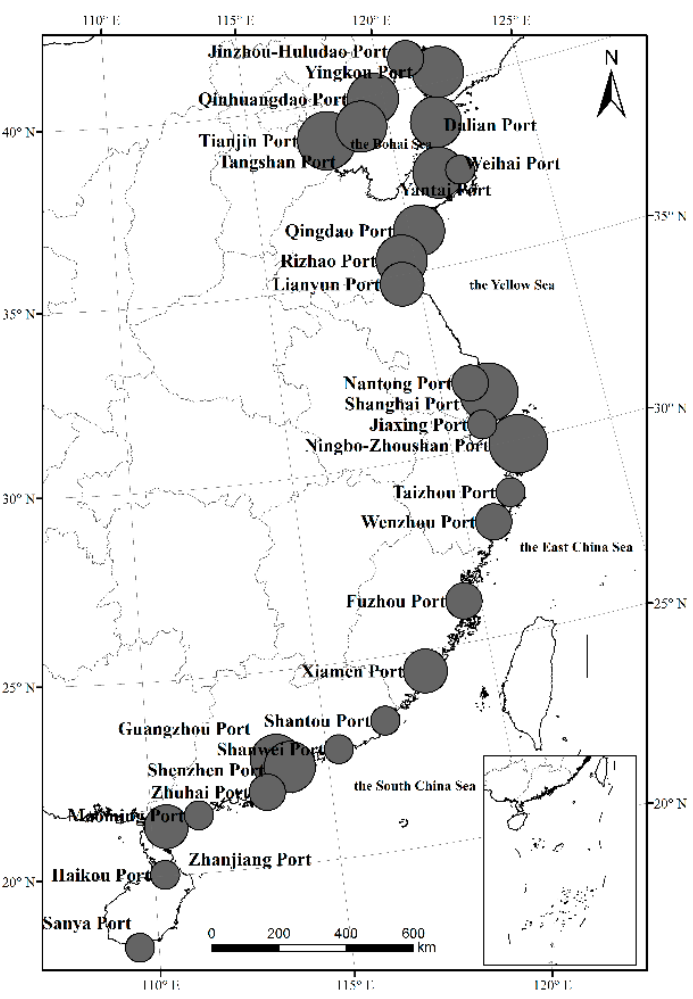

(c)

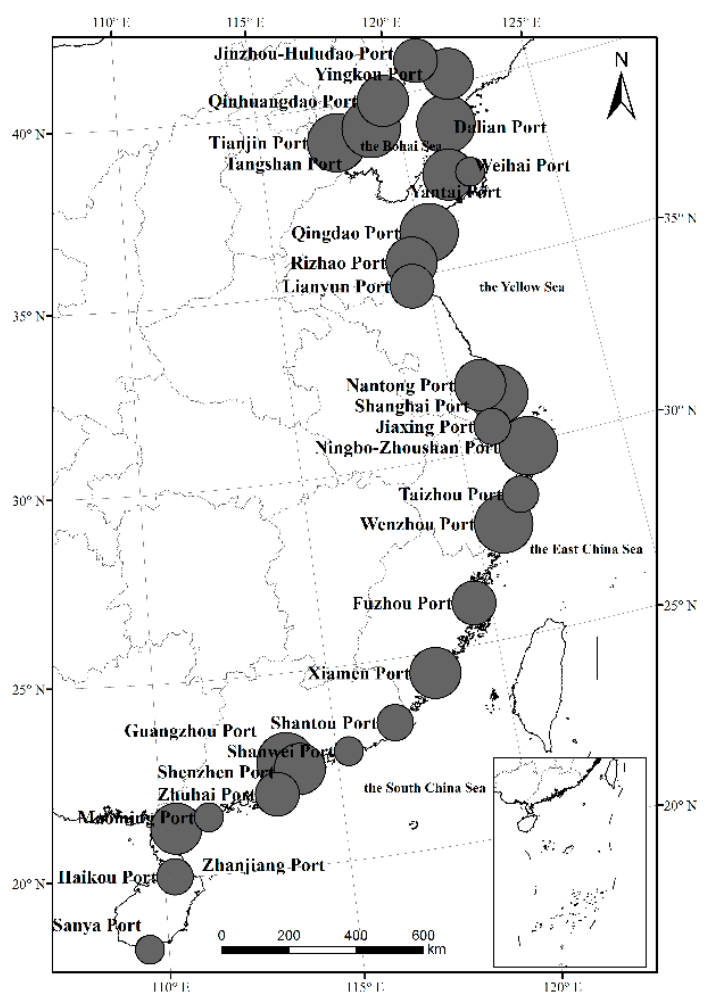

(d)

\begin{tabular}{|ccccc|}
\hline CHC & (million tons) & $\bigcirc$ & $10000.001-20000.000$ \\
$\circ$ & $0.000-5000.000$ & $\bigcirc$ & $20000.001-40000.000$ \\
& $5000.001-10000.000$ & $\bigcirc$ & $40000.001-90000.000$ \\
\hline
\end{tabular}

Figure 10. Spatiotemporal analysis of $\mathrm{CHC}$ for coastal ports in China: (a) spatiotemporal analysis of 2001 CHC for coastal ports in China; (b) spatiotemporal analysis of $2005 \mathrm{CHC}$ for coastal ports in China; (c) spatiotemporal analysis of 2010 CHC for coastal ports in China; (d) spatiotemporal analysis of 2015 CHC for coastal ports in China.

\section{Discussion}

The cargo transportation activities were carried out in the sea area near the port, without any respite, all day and night. In order to ensure normal nighttime operation similar to daytime operation, the sea area at the port is lit up at night. Using this feature, we attempted to estimate the CHC of coastal ports by observing the nighttime light data of the ports. We collected DMSP-OLS NAL data of 28 coastal ports in China from 2001 to 2010 as sample data to establish the panel model and verified it with data from 2011 to 2013. Finally, it was found that there is a long-term stable regression relationship between CHC and NAL. The fitting coefficients (R2) of regression equations were all higher than 0.9, i.e., the NAL data can be used to accurately estimate the $\mathrm{CHC}$ of coastal ports. The results have certain application values for the study of coastal port development at the regional scale, and compensate for the lack of data on $\mathrm{CHC}$ for some ports. Especially in areas where data are not available or data collection is inconvenient, the method is obviously an effective way to estimate the CHC data. The application of panel data model also makes the conclusions obtained in this paper have a broad significance, not limited to the research area.

In existing studies, DMSP-OLS stable nighttime light data is widely used in the socio-economic field, as it filters out a large number of temporary and unstable lights, including the lights of ships, which are very important for nighttime operation of ports. Hence, this paper used DMSP-OLS NAL 
data that retains such information as the data source. This data is seldom used in existing studies. Hence, to a certain degree, this study also extended the usage and values of NAL data.

Only DMSP-OLS nighttime lights data prior to 2013 has been released. Hence, the research period of this paper ends at 2013, which affects the relevance of the research. However, with innovations in technology, the update speed of future data can be improved, and the available sources of nighttime lights data are also increasing. In October 2011, the first Visible Infrared Imaging Radiometer Suite (VIIRS) sensor on board the Suomi National Polar Orbiting Partnership (S-NPP) satellite was launched. NPP/VIIRS has a higher spatial resolution and a wider radiation range than traditional DMSP/OLS data, so it may have advantages in simulating economic parameters. However, NPP/VIIRS presently only has six years of data, which is too few to build a panel model and verify accuracy. When we obtain enough samples, the data will be used to estimate the cargo handling capacity of coastal ports in future.

The predicted values of the RBAPG are generally lower than the real values. Combined with the actual situation, we speculated that the brightness of the image detected by the sensor would be influenced by air quality. Thus, AQI data of coastal cities were collected and processed, and the guesswork was confirmed. Air quality also has an impact on the authenticity of light values in night-time images, especially in areas where air quality is not perfect. AQIs can be added to later studies to perfect the panel formula, to correct images, to make the light values closer to the ground real situation, and reduce interferenceWe assume that if the AOI data were integrated into the model in future, better fitting effect might be obtained. At present, few studies have tried to estimate port cargo throughputs using night image values. This research has both methodological and practical significance.

Author Contributions: Conceptualization: Y.W.; Methodology: B.Y.; Writing-original draft: A.L.; Writing-review \& editing: W.S.

Funding: This research was funded by the National Natural Science Foundation of China (No. 41871162 and 41630749)

Acknowledgments: The authors would like to thank the anonymous reviewers for their constructive comments on an earlier version of this paper.

Conflicts of Interest: The authors declare no conflict of interest.

\section{References}

1. Chang, S. Production function and capacity utilization of the port of Mobile. Marit. Policy Manag. 1978, 5, 297-305. [CrossRef]

2. Kim, M.; Sachish, A. The structure of production, technical change and productivity in a port. Int. J. Ind. Econ. 1986, 35, 209-223. [CrossRef]

3. Tongzon, J.L. The Port of Melbourne Authority's pricing policy: Its efficiency and distribution implications. Marit. Policy Manag. 1993, 20, 197-203. [CrossRef]

4. Sun, L.; Tan, D. Research on probability distribution of port cargo throughput. J. Mar. Sci. Appl. 2008, 7, 65-68. [CrossRef]

5. Eddie, C.H.; Man, H.N.; Jane, J.X.; Tsz, L.Y. The cargo throughput response to factor cost differentials-an analysis for the port of Hong Kong. Transportmetrica 2010, 6, 235-248. [CrossRef]

6. Chang, B.K. Impact of Exchange Rate Movements, Global Economic Activity, and the BDI Volatility on Loaded Port Cargo Throughput in South Korea. Asian J. Shipp. Logist. 2016, 32, 243-248. [CrossRef]

7. Elvidge, C.D. Mapping City Lights with Nighttime Data from the DMSP Operational Linescan System. Photogramm. Eng. Remote Sens. 1997, 63, 727-734.

8. Elvidge, C.D.; Baugh, K.E.; Dietz, J.B.; Bland, T.; Sutton, P.C.; Herbert, W.K. Radiance Calibration of DMSP-OLS Low-Light Imaging Data of Human Settlements. Remote Sens. Environ. 1999, 68, 77-88. [CrossRef]

9. Witmer, F.W.; Loughlin, J. Detecting the Effects of Wars in the Caucasus Regions of Russia and Georgia Using Radiometrically Normalized DMSP-OLS Nighttime Lights Imagery. Mapp. Sci. Remote Sens. 2011, 48, 478-500. [CrossRef] 
10. Propasti, P.; Kappas, M. Assessing Satellite-Observed Nighttime Lights for Monitoring Socioeconomic Parameters in the Republic of Kazakhstan. Mapp. Sci. Remote Sens. 2012, 49, 538-557. [CrossRef]

11. Butt, M.J. Estimation of Light Pollution Using Satellite Remote Sensing and Geographic Information System Techniques. Mapp. Sci. Remote Sens. 2012, 49, 609-621. [CrossRef]

12. He, C.; Ma, Q.; Li, T.; Yang, Y.; Liu, Z. Spatiotemporal dynamics of electric power consumption in Chinese Mainland from 1995 to 2008 modeled using DMSP-OLS stable nighttime lights data. J. Geogr. Sci. 2012, 22, 125-136. [CrossRef]

13. He, C.; Ma, Q.; Li, T.; Yang, Y.; Liu, Z.; Zhang, Q. Modeling the spatiotemporal dynamics of electric power consumption in Mainland China using saturation-corrected DMSP-OLS nighttime stable light data. Int. J. Digit. Earth 2014, 7, 993-1014. [CrossRef]

14. Tian, J.; Zhao, N.; Samson, E.L.; Wang, S. Brightness of Nighttime Lights as a Proxy for Freight Traffic: A Case Study of China. IEEE J. Sel. Top. Appl. Earth Obs. Remote Sens. 2014, 7, 206-212. [CrossRef]

15. Zhao, M.; Cheng, W.; Zhou, C.; Li, M.C.; Huang, K.; Wang, N. Assessing Spatiotemporal Characteristics of Urbanization Dynamics in Southeast Asia Using Time Series of DMSP-OLS Nighttime Light Data. Remote Sens. 2018, 10, 47. [CrossRef]

16. Addison, D.M.; Stewart, B.P. Nighttime Lights Revisited: The Use of Nighttime Lights Data as a Proxy for Economic Variables. Soc. Sci. Electron. Publ. 2015, 53, 86-87. [CrossRef]

17. Yücer, E.; Erener, A. Examining Urbanization Dynamics in Turkey Using DMSP-OLS and Socio-Economic Data. J. Indian Soc. Remote Sens. 2018, 46, 1159-1169. [CrossRef]

18. Doll, C.N.H. The DMSP-OLS sensor and its data products. In CIESIN Thematic Guide to Night-Time Light Remote Sensing and Its Applications, 1st ed.; Doll, C.N.H., Ed.; Columbia University: New York, NY, USA, 2008; Volume 3, pp. 6-11.

19. Ma, T.; Xu, T.; Huang, L.; Zhou, A. A Human Settlement Composite Index (HSCI) Derived from Nighttime Luminosity Associated with Imperviousness and Vegetation Indexes. Remote Sens. 2018, 10, 455. [CrossRef]

20. Yu, S.; Zhang, Z.; Liu, F. Monitoring Population Evolution in China Using Time-Series DMSP-OLS Nightlight Imagery. Remote Sens. 2018, 10, 194. [CrossRef]

21. Stathakis, D.; Baltas, P. Seasonal population estimates based on night-time lights. Comput. Environ. Urban Syst. 2018, 68, 133-141. [CrossRef]

22. Croft, T.A. Nighttime Images of the Earth from Space. Sci. Am. 1978, 239, 86-98. [CrossRef]

23. Imhoff, M.L.; Lawrence, W.T.; Stutzer, D.C.; Elvidge, C.D. A technique for using composite DMSP-OLS ‘City Lights' satellite data to map urban area. Remote Sens. Environ. 1997, 61, 361-370. [CrossRef]

24. Elvidge, C.D.; Imhoff, M.L.; Baugh, K.E.; Hobson, V.R.; Nelson, I.; Satran, J.; Dietz, J.B.; Tuttle, B.T. Night-time lights of the world: 1994-1995. ISPRS J. Photogramm. Remote Sens. 2001, 56, 81-99. [CrossRef]

25. Shi, K.F.; Yu, B.L.; Huang, Y.X.; Wu, J.P. Evaluating the Ability of NPP-VIIRS Nighttime Light Data to Estimate the Gross Domestic Product and the Electric Power Consumption of China at Multiple Scales\&58; A Comparison with DMSP-OLS Data. Remote Sens. 2014, 6, 1705-1724. [CrossRef]

26. Kim, S.W.; Cho, K.D.; Kim, Y.S.; Choi, Y.S.; Ahn, Y.H.; Kim, Y.S. Distribution of Fishing Boats at Night in the East Sea Derived from DMSP-OLS Imagery. Korean J. Fish. Aquat. Sci. 2005, 38, 323-330. [CrossRef]

27. Nagatani, I. A methodology to create DMSP-OLS night-time mosaic image for monitoring fishing boats. Proc. Asia-Pac. Adv. Netw. 2010, 30, 229. [CrossRef]

28. Shi, K.F.; Yu, B.L.; Hu, Y.J.; Huang, C.; Chen, Y.; Huang, Y.X.; Chen, Z.Q.; Wu, J. Modeling and mapping total freight traffic in China using NPP-VIIRS nighttime light composite data. Mapp. Sci. Remote Sens. 2015, 52, 274-289. [CrossRef]

29. Li, C.; Chen, G.; Luo, J.; Li, S.; Ye, H. Port economics comprehensive scores for major cities in the Yangtze Valley, China using the DMSP-OLS night-time light imagery. Int. J. Remote Sens. 2017, 38, 1-23. [CrossRef]

30. Chu, Z.F. Logistics and economic growth: A panel data approach. Ann. Reg. Sci. 2012, 49, 87-102. [CrossRef]

31. Lakew, P.A. Essays on Air Cargo Cost Structures, Airport Traffic, and Airport Delays: Panel Data Analysis of the U.S. Airline Industry. Ph.D. Dissertation, University of California, Irvine, CA, USA, 2014. Available online: https:/ / escholarship.org/uc/item/9vp9621m (accessed on 21 January 2019).

32. Guo, X.; Ren, D.; Shi, J. Carbon emissions, logistics volume and GDP in China: Empirical analysis based on panel data model. Environ. Sci. Pollut. Res. 2016, 23, 1-10. [CrossRef] [PubMed]

33. Baltagi, B.H. Econometric analysis of panel data. Econom. Theory 2001, 5, 747-754. 
34. Seto, K.C.; Kaufmann, R.K. Modeling the Drivers of Urban Land Use Change in the Pearl River Delta, China. Land Econ. 2003, 79, 106-121. [CrossRef]

35. Hsiao, C. Analysis of Panel Data; Cambridge University Press: New York, NY, USA, 1986.

36. Shi, K.; Chen, Y.; Yu, B.; Xu, T.; Chen, Z.; Liu, R.; Li, L.; Wu, J. Modeling spatiotemporal CO2 (carbon dioxide) emission dynamics in China from DMSP-OLS nighttime stable light data using panel data analysis. Appl. Energy 2016, 168, 523-533. [CrossRef]

37. Wei, Y.; Liu, H.; Song, W.; Yu, B.; Xiu, C. Normalization of time series DMSP-OLS nighttime light images for urban growth analysis with Pseudo Invariant Features. Landsc. Urban Plan. 2014, 128, 1-13. [CrossRef]

38. Elvidge, C.; Ziskin, D.; Baugh, K.; Tuttle, B.; Ghosh, T.; Pack, D.; Erwin, E.; Zhizhin, M. A Fifteen Year Record of Global Natural Gas Flaring Derived from Satellite Data. Energies 2009, 2, 595-622. [CrossRef]

39. Adhikari, R. A neural network based linear ensemble framework for time series forecasting. Neurocomputing 2015, 157, 231-242. [CrossRef]

40. Chang, Y.T.; Park, H.; Lee, S.; Kim, E. Have Emission Control Areas (ECAs) harmed port efficiency in Europe? Transp. Res. Part D Transp. Environ. 2018, 58, 39-53. [CrossRef]

41. Rassam, M.; Hadi, R.F.; Hadi, G. Estimation of perishable cargo transportation demand by a panel data model. Urban Manag. 2015, 13, 93-102.

42. Wang, S.S.; Zhou, D.Q.; Zhou, P.; Wang, Q.W. $\mathrm{CO}_{2}$ emissions, energy consumption and economic growth in China: A panel data analysis. Energy Policy 2011, 39, 4870-4875. [CrossRef]

43. Levin, A.; Lin, C.; James, C. Unit root tests in panel data: Asymptotic and finite-sample properties. Economet 2002, 108, 1-24. [CrossRef]

44. Fleissig, A.R.; Strauss, J. Unit root tests on real wage panel data for the G7. Econ. Lett. 1997, 56, 149-155. [CrossRef]

45. Rault, C.; Drine, I. Does the Balassa-Samuelson Hypothesis Hold for Asian Countries? In An Empirical Analysis Using Panel Data Cointegration Tests; William Davidson Institute Working Papers; William Davidson Institute: Ann Arbor, MI, USA, 2002; p. 4. [CrossRef]

46. Pedroni, P. Critical values for cointegration tests in heterogeneous panels with multiple regressors. Oxf. Bull. Econ. Stat. 1999, 61, 653-670. [CrossRef]

47. Örsal, D.D.K. Comparison of panel cointegration tests. Econ. Bull. 2007, 3, 1-20.

48. Kim, C.J.; Nelson, C.R. Estimation of a forward-looking monetary policy rule: A time-varying parameter model using ex post data. J. Monet. Econ. 2006, 53, 1949-1966. [CrossRef]

49. Yang, J.; Guan, Y.Y.; Xia, J.H.; Jin, C.; Li, X.M. Spatiotemporal variation characteridtics of green space ecosystem service value at urban fringes: A case study on Ganjingzi District in Dalian, China. Sci. Total Environ. 2018, 639, 1453-1461. [CrossRef] [PubMed]

50. Liu, J.; Wang, J.; Wang, S.H.; Wang, J.F.; Deng, G.P. Analysis and simulation of the spatiotemporal evolution pattern of tourism lands at the Natural World Heritage Site Jiuzhaigou, China. Habitat Int. 2018, 79, 74-88. [CrossRef]

(C) 2019 by the authors. Licensee MDPI, Basel, Switzerland. This article is an open access article distributed under the terms and conditions of the Creative Commons Attribution (CC BY) license (http:// creativecommons.org/licenses/by/4.0/). 